\title{
JOURNAL.RU
}

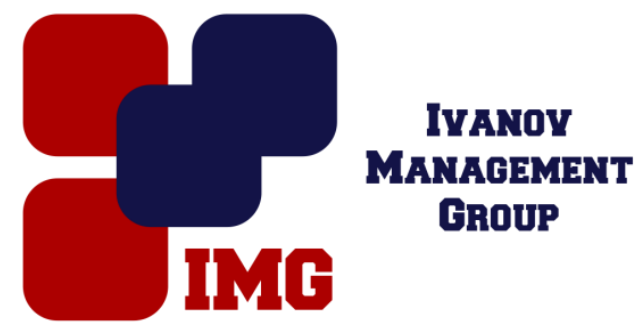

Морозова Е.В. Курский государственный медиџинский университет Курск, Россия

doi: 10.18411/1j-31-05-2017-39

idsp 000001:1j-31-05-2017-39

\section{Использование биотестирования как интегрального метода оценки токсичности факторов окружающей среды}

Многообразные загрязняющие вещества, попадая в окружающую среду, могут претерпевать различные изменения, при этом усиливая свое токсическое действие. Это служит толчком для разработки новых, интегральных методов оценки контроля качества ряда объектов окружающей среды, в том числе воды, воздуха и почвы, позволяющих оценить их качество и возможную опасность различных источников загрязнения.

Традиционная эколого-гигиеническая оценка химического загрязнения объектов окружающей среды, основанная на санитарно-химических анализах, нашла широкое применение в практике. Однако, в связи с появление новых токсичных веществ, она не дает полного преставления об опасности объектов окружающей среды. В связи с этим представляется необходимым разработка новых методов оценки токсичности. С этой целью и распространяется практика биотестирования на тест-объектах для характеристики оценки токсического эффекта.

Биотестирование (англ. bioassay) - процедура установления токсичности среды с помощью тест-объектов, сигнализирующих об опасности независимо от того, какие вещества и в каком сочетании вызывают изменения жизненно важных функций у тест-объектов.

Поиск исторических корней применения биотестирования уводит нас в период античности, когда во дворцах тиранов, опасающихся отравления, всю пищу пробовали специальные служители. В средние века эта традиция отнюдь не была забыта. Становление гуманистического мировоззрения в эпоху 
Ренессанса способствовало тому, что со временем на эксперименты на живых людях был введен социальный запрет. Но, несмотря на то что развитие науки ввело в арсенал исследователей множество новых аналитических методов, разнообразные эксперименты на человеке проводили вплоть до настоящего времени, особенно широко - в Германии в период Второй мировой войны. Проводят их и до сих пор, например, в качестве последней стадии при испытании новых лекарственных препаратов на группах добровольцев. Использование в экспериментах различных животных также имеет богатые традиции. Тем не менее, отношение к животным постепенно менялось. В XIX веке эти изменения нашли свое осмысление и философское выражение, в частности, в этическом направлении утилитаризма Иеремии Бентама, который полагал, что животные способны испытывать отрицательные эмоции, и считал, что человек должен стремиться к уменьшению их страданий. Получивший дальнейшее развитие в XX веке плюралистический утилитаризм, ставя ценность человеческой жизни выше ценности жизни животных, тем не менее, проводит различие между животными, стоящими на различных уровнях организации, и обосновывает необходимость постановки экспериментов преимущественно на низкоорганизованных лабораторных животных. Сейчас в России и за рубежом для биотестирования в основном используются различные простейшие микроорганизмы (инфузории, гидробионты, фотобактерии и др.).

В выявлении антропогенного загрязнения среды наряду с химикоаналитическими методами используются методы биотестирования. Живые организмы способны воспринимать более низкие концентрации веществ, чем любой аналитический датчик, в связи с чем биота может быть подвержена токсическим воздействиям, не регистрируемым техническими средствами. Биотестирование представляет собой методический прием, основанный на оценке действий факторов окружающей среды, в том числе и токсического, на организм, его отдельную функцию или систему органов и тканей. Кроме выбора биотеста существенную роль играет выбор тест-реакции - того параметра организма, который собственно и измеряется при тестировании.

Наиболее информативны интегральные параметры, характеризующие общее состояние живой системы соответствующего уровня. Для отдельных организмов к интегральным параметрам относят характеристики выживаемости, роста, плодовитости, тогда как физиологические, биохимические, гистологические и прочие параметры относят к частным. Для популяций интегральными параметрами являются численность и биомасса, а для экосистем 
- характеристики видового состава, активности продукции и деструкции органического вещества.

С увеличением интегральной тест-реакции повышается "экологический реализм" теста, но обычно снижаются его оперативность и чувствительность. Функциональные параметры оказываются более лабильными, чем структурные, а параметры клеточного и молекулярного уровней проигрывают в отношении экологической информативности, но выигрывают в отношении чувствительности, оперативности и воспроизводимости.

Для примера приведем биотестирование, в котором в качестве тестсистемы берем инфузорий. Этот метод является наиболее простым, доступным для практических лабораторий и наиболее чувствительным.

В литературе есть упоминания об использовании в качестве тест-объектов нескольких десятков инфузорий, из которых у нас наиболее часто применяют 2 вида: Parameciumcaudatum и Tetrahymenapyriformis.Кроме того, используют также представителей родовStylonychiaиColpoda

Суть метода заключается в том, что на культуру инфузорий в оптической кювете наслаивают исследуемый субстрат в жидкой фазе. Инфузории, обладая высокой подвижностью, могут свободно мигрировать из одной фазы в другую, но присутствие в верхней фазе токсических веществ сдерживает этот процесс (отрицательный хемотаксис). Через некоторое время устанавливается равновесие по концентрации инфузорий между верхней и нижней фазой, причем концентрация их в верхней фазе зависит от концентрации в ней токсического вещества. Через тридцать минут концентрацию инфузорий в верхней фазе измеряют прибором БИОТЕСТЕР и сравнивают с концентрацией в контроле (водопроводная вода). Результат выражается в виде безразмерной величины индекса токсичности по разнице концентраций инфузорий в верхних фазах опыта и контроля.

Установлено, что на разных фазах роста культура инфузорий обладает разной чувствительностью к воздействию токсических веществ, и эти различия могут быть весьма существенными. Поэтому для получения однозначного и объективного ответа культуру инфузорий берут на одной фазе роста (стационарная фаза).

В нашей лаборатории также присутствует оборудование для биотестирования. Прибор экологического контроля "Биотокс-10М" предназначен для быстрого количественного контроля степени интегральной токсичности проб воды и водных вытяжек, спиртов, воздушной среды, почвы, а 
также отдельных химических соединений, материалов, включая полимеры, для медицинских, санитарно-гигиенических и экологических целей. В основу работы прибора положен биолюминесцентный анализ.

Принцип работы прибора «Биотокс-10М» заключается в регистрации слабого свечения высокочувствительного биосенсора «Эколюм» (ТУ 6-09-20236-01). Изменение свечения проявляется в процессе биолюминесцентной реакции на наличие токсичных химических веществ в водном растворе.

Для измерения токсичности используется сравнительный анализ интенсивности свечения водного раствора контрольного биосенсора и биосенсора с пробой. В процессе измерения используются две пробирки - одна с дистиллированной водой, выступающая в качестве эталона, другая - с исследуемой пробой. В обе пробирки добавляется приготовленный раствор биосенсора, и они поочередно вставляются в кюветное отделение прибора.

Свечение биосенсора регистрируется с помощью фотоэлектронного умножителя (ФЭУ), работающего в режиме счёта анодных импульсов. Сигнал формируется в виде последовательности отдельных импульсов тока, снимаемых с анода ФЭУ. Частота следования импульсов пропорциональна интенсивности люминесценции. Изменение интенсивности биолюминесценции пропорционально токсическому эффекту.

Спектральный диапазон длин волн регистрируемого свечения составляет 300-600нм. Область максимальной спектральной чувствительности ФЭУ располагается в диапазоне 380-490нм.

Уровень собственных шумов прибора (частота следования импульсов при отсутствии источника светового сигнала в кюветном отделении), не должен превышать 200имп./сек. В технических характеристиках этот параметр называется уровнем шумов нулевого сигнала (Хо). Измеряемый диапазон интенсивности свечения биосенсора от Хо (200имп./сек.) до 999999имп./сек.

Величина измеряемой токсичности от 1 до 99. По величине индекса токсичности (Т), анализируемые пробы классифицируются на три группы, что позволяет сделать вывод о степени токсичности пробы:

1. Т меньше 20 - образец не токсичен (допустимая степень токсичности)

2. Т от 20 до 50 - образец токсичен

3. Т равно или больше 50 - образец сильно токсичен. 
В дальнейшем мы планируем изучение различных методик измерения интегральной токсичности с помощью прибора "Биотокс 10М" и их внедрение в обиход нашей лаборатории.

1. Бубнов А.Г. и др. Биотестовый анализ - интегральный метод оценки качества окружающей среды: учебно-методическое пособие / под общей редакцией В.И. Гриневича; ГОУ ВПО Иван. гос. хим.-технол. ун-т. Иваново. 2007. 112 с.

2. Виноходов Д.О. Научные основы биотестирования с использованием инфузорий: диссертация ... доктора биологических наук : 03.00.23 / Виноходов Дмитрий Олегович; Санкт-Петербург, 2007. 353 с.: ил. РГБ ОД, 71 07-3/346

3. Евгеньев М.И. Тест-методы и экология //Соросовский образовательный журнал. 1999. №11. C. 29-34

4. Мелехова О.П., Егорова Е.И. и др. Биологический контроль окружающей среды: биоиндикация и биотестирование: учеб. пособие для студ. высш. учеб. заведений // М.: Издательский центр "Академия". 2007. 288 с.

5. Руководство по эксплуатации прибора "Биотокс 10М" 